\title{
AGROPRIMATECH \\ KONFLIK AGRARIA PENGUASAAN TANAH ULAYAT MASYARAKAT KABUPATEN PULAU MOROTAI PROVINSI MALUKU UTARA
}

\author{
ZULKIFLI TAIB ${ }^{1}$, FIKARWIN ZUSKA ${ }^{2}$ \\ 1,2 Program Studi Pengelolaan Sumber Daya Alam dan Lingkungan, \\ Universitas Sumatera Utara \\ Email: zulkiflitaib55@gmail.com
}

\begin{abstract}
ABSTRAK
Konflik agraria tanah ulayat sering terjadi di berbagai daerah di Indonesia terutama pada masalah pengelolaan sumber daya alam dengan asumsi untuk meningkatkan pertumbuhan ekonomi. Hal ini juga terjadi di kawasan Perbatasan bagian timur Indonesia yaitu Kabupaten Pulau Morotai yang merupakan kabupaten baru pemekaran dari Kabupaten Halmahera Utara Provinsi Maluku Utara. Berbagai macam pendekatan untuk mencari solusi penyelesaian yang difasilitasi oleh pihak Pemerintah Kabupaten Pulau Morotai, tetapi gejolak konflik selalu saja terjadi. Kekuasaan organisasi tertinggi ada pada negara yang diharapkan dapat memfalisitasi penyelesaian sengketa berada pada posisi delimatis disatu sisi pemerintah mengupayakan adanya pertumbuhan ekonomi melalui investasi dan penanaman modal disisi lain masyarakat mengklaim tanah yang suda ditempati sejak turun-temurun adalah tanah mereka. Diperlukan suatu model pembangunan yang berkelanjutan yaitu meningkatkan pertumbuhan ekonomi tetapi tidak mengabaikan kepentingan masyarakat pada tataran sosial ekonomi untuk kesejahteraan masyarakat. Dengan model tersebut kita akan mencapai pembangunan yang berwawasan lingkungan yaitu meningkatkan pertumbuhan ekonomi dan mewariskan sumberdaya alam kepada generasi yang akan dating.
\end{abstract}

Kata Kunci: Konflik, Agraria, Penguasaan, Ekonomi.

\section{PENDAHULUAN}

Tanah pada dataran wilayah Indonesia menjadi tempat untuk sumber penghidupan bagi masyarakat dan pendapatan bagi yang berpenghasilan dari bidang pertanian. Dari aspek politik tanah merupakan tempat, batas, dan letak wilayah yurisdiksi penduduk indonesia. Dari aspek sosial tanah merupakan ruang berlangsunya hubungan baik antara sesama penduduk di indonesia. Konflik secara umum didefenisikan sebagai suatu proses sosial, dimana dua orang atau kelompok berusaha menyingkirkan pihak lain dengan jalan menghancurkanya atau membuatnya tidak berdaya (Hondropuspito 1992)

Secara hukum hubungan manusia (subjek) Indonesia dengan tanah (objek) telah tersurat dalam Undang-Undang Nomor 5 Tahun 1960 tentang peraturan Dasar Pokok-pokok Agraria (selanjutnya disingkat UUPA), meberikan penegasan pengaturan terkait permukaan bumi dalam pengertian yuridis yang disebut hak-hak penguasaan atas tanah. Penguasaan atas tanah meliputi hubungan antara individu (perseorangan), badan hukum ataupun masyarakat sebagai suatu kolektifitas dengan tanah yang dihaki yang mengakibatkan lahirnya hak dan kewajiban. Bentuk penguasaan tanah dapat berlangsung secara terus menerus dan dapat pula bersifat sementara. Hak atas tanah sebagai suatu hubungan hukum konkrit memberikan serangkaian wewenang, kewajiban dan/atau larangan 
bagi pemegang hak atas permukaan bumi yang berdimensi dua untuk berbuat "sesuatu" mengenai tanah yang dihaki. Istilah "sesuatu" yang boleh, wajib atau dilarang untuk diperbuat yang merupakan isi hak penguasaan itulah yang menjadi kriteria atau tolak ukur pembeda diantara hak-hak penguasaan atas tanah yang diatur dalam hukum tanah. Ronal Mawuntu meyebutkan satu hal yang sampai saat ini masih diperdebatkan dan belum mendapatkan penafsiran yang sama yaitu makna "hak penguasaan negara".

Berdasarkan aspek agraria, kebijakan pemerintah dibidang pertanahan sangat dipengaruhi dan diintervensi perusahan-perusahan multinasional. Cara pandang rezim kapitalisme yang melihat tanah sebagai barang komuditas, sehingga tanah dilepaskan dari ikatan-ikatan sosial yang melekat yang dapat mengakibatkan rusaknya sendi-sendi kehidupan bermasyarakat baik cepat atau lambat pada giliranya akan menimbulkan gejolak perlawanan. Dimensi konflik pertanaham antara pemegang hak atas tanah yang berhadapan dengan pemerintah dan penguasa cenderung mengalami perubahan sebagi akibat konfigurasi tanah yang selalu berubah, berdampak pada timbulnya banyak benturan kepentingan yang terus berkembang dengan beragam modus dan pola, sehingga diperlukan metode pendekatan penyelesaian sengketa yang dapat memberikan keadailan dan kepastian hukum bagi masyarakat sengketa ini dengan bebagai modus bahkan sampai menimbulkan korban.

Hal tersebut juga terjadi di Kabupaten Pulau Morotai Provinsi maluku Utara, tipologi konflik pertanahan yang muncul terkait pemerintah dan Aparat TNI$A U$ vs masyarakat pemegang hak. Berawal dari tahun 1980 dimana status provinsi maluku utara belum terpisahkan dari provinsi maluku kala itu TNI-AU yang bertugas dimorotai memberi patok pembatas sejumlah lahan kepemilikan warga masyarakat adat morotai dengan luas lahan tanah 1.125 hektar. Merasa tanahnya diambil oleh aparat TNI-AU pada tanggal 12 Januari 2012, warga masyarakat dan elemen ormas melakukan aksi protes dan mencabut patok-patok yang ada. Aksi protes warga masyarakat masih terjadi hingga sekarang, selain tuntutan tersebut masyarakat juga meminta kejelasan tentang panita khusus tapal batas yang dibentuk oleh DPRD dan Pemerintah Daerah pada tahun 2010.

Masyarakat merasa kecewa dengan rentang waktu 3 tahun belalu tidak ada kejelasan dari panitia khusus tapal batas. Masyarakat juga menuntut ke pemerintah agar menyelesaikan konflik tanah mereka dan menginventarisir lahanlahan milik warga yang disengketakan. Dengan adanya desakan warga masyarakat untuk penyelesaian tanah sengketa Pada tanggal 31 agustus 2013 pemkab pulau morotai mempertemukan antara TNI-AU dengan masyarakat tetapi kedua tim saling mempertahankan hak dan pendapat mereka sehingga pemerintah Kabupaten Pulau Morotai mengambil keputusan dengan membentuk tim khusus tapal batas untuk mengkaji dan mencari data atas hak tanah yang disengketakan antara masyarakat dengan TNI-AU ini agar mendapat penyelesaianya.

Persoalan yang terjadi antara konflik agraria penguasaan tanah ulayat di kabupaten pulau morotai sebagai daerah perbatasan 3T harus diseriusi baik oleh pemerintah daerah maupun pemerintah pusat sehingga tidak menimbulkan korban jiwa. Sesuai dengan latar belakang ini penulis merasa tertarik untuk melakukan penelitian dengan judul; Konflik Agraria Penguasaan Tanah Ulayat Masyarakat Perbatasan 3T Kabupaten Pulau Morotai Provinsi Maluku Utara. Dengan pokok permasalahan (1) Bagaimana kebijakan pemerintah daerah meyelesaikan sengketa tanah ulayat. (2) sejauh mana win-wins solition antara pihak yang bersengketa.

\section{METODE PENELITIAN}

Penulisan artikel ini menggunakan pendekatan metode penelitian normatif. Dengan menggunakan studi dokumen yang terdiri dari bahan hukum primer dan bahan hukum sekunder. Bahan hukum primer didapat pada informasi dari berbagai bacaan konvensional maupun berita-berita dari media dan informasi yang diakses lewat jaringan internet serta data BPS Kabupaten Pulau Morotai. Sedangkan 
bahan sekunder yang diambil pada hukum empiris (yuridis empiris) yaitu regulasi yang suda dibakukan berupa Undang-Undang
Dasar 1945 dan Peraturan Mentri Negara Agraria.

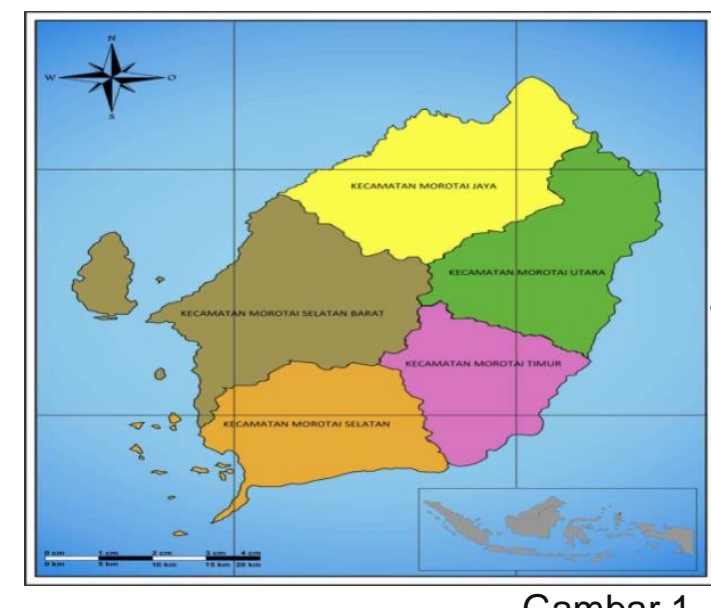

\section{HASIL DAN PEMBAHSAN}

Kabupaten Pulau Morotai merupakan kabupaten baru, sebagai hasil pemekaran dari Kabupaten Halmahera Utara Provinsi Maluku Utara yang diresmikan oleh Menteri Dalam Negeri Indonesia Mardiyanto. dengan luas wilayah total $4.301,53 \mathrm{~km}^{2}$, yang meliputi wilayah laut $1.970,93 \mathrm{~km}^{2}$, wilayah daratan $2.330,60 \mathrm{~km}^{2}$. Secara geografis wilayah Kabupaten Pulau Morotai berada pada posisi kordinat $2^{0} 00$ sampai $2^{0} 40 \mathrm{LU}$ dan $28^{0} 15$ sampai $28^{0} 40$ BT. Batas- batas wilayah Kabupaten Pulau Morotai adalah, Sebelah Utara berbatasan dengan Samudera Pasifik, Sebelah Selatan berbatasan dengan Selat Morotai, Sebela Timur berbatasan dengan Laut Halmahera, Sebelah Barat berbatasan dengan Laut Sulawesi. Kabupaten Pulau Morotai dengan ibu Kota Daruba, yang dimekarkan pada tahun 2009 memiliki 5 kecamatan dan 88 Desa. Berdasarkan data tahun 2017 jumlah penduduk Kabupaten Pulau Morotai sebayak 72.051 jiwa yang terdiri dari $21.403 \mathrm{KK}$ dan rasio kepadatan penduduk $/ \mathrm{km} 2$ untuk kecamatan morotai selatan 0.50. Kecamatan Morotai Selatan Barat berkisar 0,18. Kecamatan Morotai Timur berkisar 0,23, Kecamatan Morotai Utara berkisar 0,22. Kecamatan Morotai jaya berkisar 0,17 .Selain itu letak Kabupaten Pulau Morotai sangat strategis karena berada di titik silang lalu-lintas transportasi antar benua dikawasan pasifik

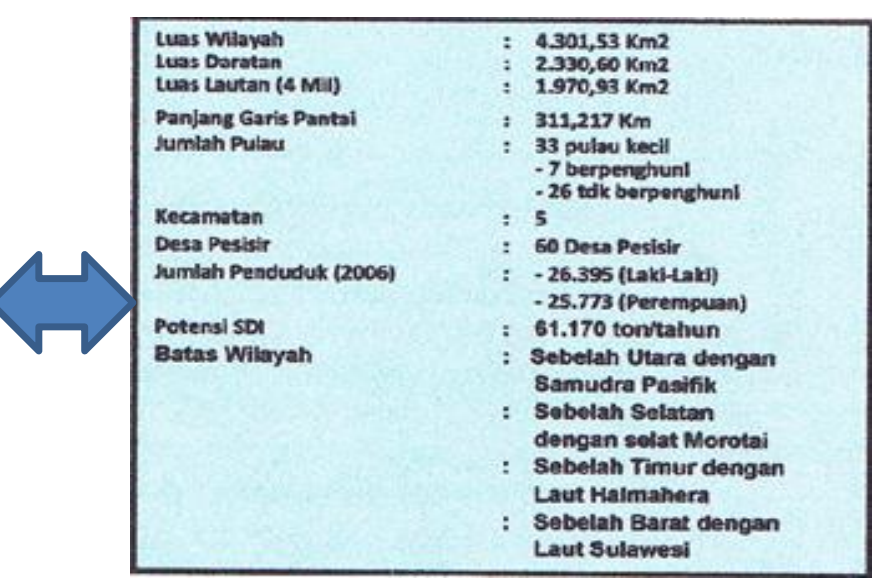

yang menjadi pintu masuk menuju kawasan perdagangan pasifik dengan memiliki bandara dengan 7 (tujuh) runway dan pelabuhan peninggalan perang dunia II

yang dapat direnovasi dan ditingkatkan fungsinya menjadi Hub-port internasional. Proporsi jumlah penduduk miskin yang tersebar di Kabupaten Pulau Morotai sebanyak 45.446 jiwa. Sehubungan permasalahan dengan pemasangan patok oleh AURI pada lahan masyarakat dengan asusumsi bahwa batas landasan penerbangan diareal bandara sesuai dengan areal landasan pacu pesawat. Pada tahun 1942 jepang menduduki pulau morotai dan membuat lapangan terbang tersebut, dan pada tahun 1950 AURI masuk kemorotai dan langsung mengelolah lapangan terbang dan asrama. Setiap pergantian Komendan Lanud AURI selalu ada perubahan kebijakan tetapi tidak berpihak kepada tuntutan masyarakat. Pada tahun 2010, pemerintah kabupaten pulau morotai yang dipimpin oleh $\mathrm{Pj}$. Bupati H.Sukemi Sahab mengeluarkan surat keputusan No 1593/101/PM/2010 tentang pembentukan tim peyelesaian tapal batas lahan Masyarakat dengan lahan AURI tim penyelesaian ini diberi tugas untuk (1) mendata aspirasi masyarakat yang berkaitan dengan masalah kepemilikan batas lahan sengketa. (2) memverifikasi data kemudian melakukan pengkajian secara komprehensif melibatkan pihak- 
pihak yang berkompeten. (3) melakukan koordinasi guna mencari solusinya. (4) meneruskan hasil negoiasi dengan pihak yang bersengketa kepada bupati. (5) membuat rekomendasi penyelesaian yang dimaksud. Peran Pemkab Pulau Morotai dalam konsiliasi yang dilakukan dengan mempertemukan kedua pihak antara masyarakat dengan TNI-AU. Pertemuan tersebut memberikan peluang kepada kedua pihak untuk berdiskusi secara terbuka atau berdialog tentang kepentingan masing-masing yang berkaitan dengan konflik. Sejak tahun 2010 sampai 2013 telah terjadi beberapa kali pemerintah Kabupaten PulauMorotai telah memberikan fasilitas pertemuan baik waktu dan tempat pertemuan maupun peran selanjutnya sebagai mediator para pihak yang bersengketa untuk melakukan musyawarah atau perundingan guna mendapatkan penyelesaian konflik.

$$
\text { Peran pemerintah sebagai }
$$

fasilitator dalam mempertemukan para pihak untuk berdiskusi atau berdialog secara terbuka tidak dapat menyelesaikan konflik karena para pihak yang berkonflik tetap mempertahankan kepentingan masing-masing. Di satu pihak, TNIAUberpedoman pada regulasi atau aturan hukum bahwa penguasaan tanah yang dilakukan TNI-AU adalah untuk mengamankan aset negara. Di lain pihak, masyarakat merasa bahwa tanah tersebut merupakan tanah warisan nenek moyang atau leluhur yang mereka miliki dan kuasai secara turun temurun dan dibuktikan dengan ada perkebunan kelapa dan mangga yang sudah berumur hampir seratus tahun. Perbedaan sudut pandang ini mengakibatkan masing-masing pihak bertahan pada kepentingannya, sehingga tidakada titik temu. Masyarakat menginginkan agar tanah tersebut dapat dikembalikan hak penguasaannya kepada mereka. Selama ini, tanah tersebut merupakan sumber penghidupan atau sumber ekonomi masyarakat, sementara TNI-AU juga mempertahankan karena telah memperoleh legitimasi hukum dari negara untuk mengamankan aset tersebut. Berpijak dari proses yang penyelesaian konflik pertanahan, menurut penulis terdapat 2 (dua) faktor yang perlu diperhatikan untuk men-jamin penerapan paradigma win-win solution dalam penyelesaian sengketa. Pertama, kedudukan partisipasi para pihak yang bersengketa. Proses penyelesaian sengketa diluar pengadilan yang melibatkan Pihak Aparat TNI-AU dengan masyarakat haruslah berada dalam keadaan setara, tidak di-benarkah salah satu pihak berada dalam kedudukan subordinasi disebabkan karena rendahnya pengetahuan, kemiskinan, atau ketiadaan bukti formil penguasaan. Hal ini akan melemahkan kedudukannya dalam mendeskripsikan hubungannya dengan tanah serta keinginan pemegang hak sebagai kompensasi atas dampak putusnya hubungan dengan tanah. Demikian halnya pihak AURI tidak dapat diposisikan sebagai pihak superior hanya karena mendapatkan dukungan Pemerintah atas nama kebijakan pembangunan melalui investasi. Kedua, peran mediator. Mediator merupakan aktor kunci keberhasil-an proses mediasi sebagai cara penyelesaian konflik. Mediasi menurut Stephen Covey bukan-lah semata-mata tehnik kepribadian, akan tetapi lebih pada paradigma yang komprehensif tentang interaksi manusia. $\mathrm{Hal}$ ini hanya dapat diperoleh ketika orang bisa bersikap dewasa, berintegritas dan bermentalitas abudance.

\section{A. Pengakuan Hak Ulayat Masyarakat Hukum Adat Melalui Pentapan Pemerintah}

Secara yuridis ketika ditelah secara mendalam bahwa ada berbagai peraturan perundang-undangan yang telah mengatur keberadaan hak ulayat masyarakat. Peraturan perundang-undangan tersebut diantaranya:

\section{Undang-Undang Nomor 5 Tahun 1960 Tentang Peraturan Dasar Pokok-Pokok Agraria.}

UUPA secara tegas menggunakan hukum adat sebagai sumber hukum formal. Lahirnya UUPA ini adalah sebuah kegelisahan negara Indonesia untuk keluar dari konsep hukum Kolonial Belanda yang menyebabkan terjadi dualisme hukum dalam pengaturan hukum tanah nasional, yaitu adanya tanah-tanah yang tunduk pada hukum Barat dan terdapat tanah- 
tanah yang tunduk pada hukum adat.Oleh sebab itu UUPA hadir sebagai penerobos untuk menghapus dualisme hukum tersebut, sekaligus UUPA memegang kuat konsep bahwa pemilik hak ulayat adalah masyarakat hukum adat. $\mathrm{Hal}$ ini terlihatdalam Pasal 3 UUPA yang menyebutkan "Dengan mengingat ketentuan-ketentuan dalam Pasal 1 dan 2 pelaksanaan Hak Ulayat dan hak-hak yang serupa itu dari masyarakat-masyarakat hukum adat, sepanjang menurut kenyataannya masih ada, harus sedemikianrupa sehingga sesuai dengan kepentingan nasional dan Negara, yang berdasarkan atas persatuan bangsa sertatidak boleh bertentangan dengan Undang-undang dan peraturan-peraturan lain yang lebih tinggi"

\section{Undang-Undang Nomor 41 Tahun 1999 Tentang Kehutanan.}

Keberadaan masyarakat hukum adat termuat dalam Pasal 67 ayat (1) Undang-Undang Kehutanan menegaskan bahwa keberadaan masyarakat hukum adat menurut kenyataannya memenuhi unsur: a) masyarakatnya masih dalam bentuk paguyuban; b) ada kelembagaan dalam bentuk perangkat penguasaanadatnya; c) ada wilayah hukum adat yang jelas; d) ada pranata dan perangkat hukum yang khususnyaperadilan adat yang masih ditaati; e) mengadakan pemungutan hasil hutan di wilayah hutan sekitarnya untuk memenuhi kebutuhan hidupnya seharihari. Selanjutnya dalam Pasal 67 ayat (2) menetapkan standar normatif untuk mengakui keberadaan masyarakat hukum adat, yakni melalui penetapanyang termuat dalam peraturan daerah. Dalam kenyataannya pelaksanaan penetapan masyarakat hukum adat (termasuk hak ulayat) mengalami persoalan yang sangkat kompleks. Hal tersebut akan memakan waktu yang lama dan melalui mekanisme yang rumit serta akan terjadi konflik kepentingan yang tidak dipungkiri akan berpengaruh pada kepentingan elit politik baik pusat maupun daerah, yang berakibat pada terabaikannya hak-hak ulayat masyarakat hukum adat.

\section{Undang-Undang Nomor 32 Tahun}

\section{Tentang Perlindungan Dan Pengelolaan Lingkungan Hidup (UUPLH).}

Pengaturan terkait keberadaan masyarakat hukumadat beserta hakhaknya dalam UUPLH menegaskan bahwa masyarakat hukum adat adalah kelompok masyarakat yang secara turun temurun bermukim diwilayah geografis tertentu karena adanya ikatan pada asal usul leluhur, adanya hubungan yang kuat denganlingkungan hidup, serta adanya sistem nilai yang menentukan pranata ekonomi, politik, sosial, dan hukum. UUPLH memberikan kewenangan kepada pemerintah pusat dan pemerintah daerah untuk menetapkan kebijakan mengenai tata cara pengakuan keberadaan masyarakat hukum adat, kearifan lokal, dan hak masyarakat hukum adat yang terkait dengan perlindungan dan pengelolaan lingkungan hidup, serta menetapkan kebijakan mengenai tata cara pengakuan keberadaan masyarakat hukum adat, kearifan lokal,dan hak masyarakat hukum adat yang terkait dengan perlindungan dan pengelolaan lingkungan hidup pada tingkat provinsi.

\section{Undang-Undang Nomor 6 Tahun 2014 Tentang Desa (UU Desa). \\ Undang-Undang Desa tidak secara} tegas menyatakan keberadaan hak ulayat, akan tetapi dapat dilihat bahwa hanya pada penegasan mengenai keberadaan desa adat beserta hak dan asal-usul tersebut. Berdasrkan uraian tersebut, maka pengakuan hakulayat masyarakat hukum adat dengan sendirinya dapat dikatakan bahwa diwajibkan melalui penetapan pemerintah. Namun perlu untuk dikajih kembali bahwa terkait hak ulayat, UUPA secara tegas berpangkalpada ketentuan Pasal 3 dan Pasal 5 yang menegaskan bahwa hukum agararia mengakui keberadaan hakulayat masyarakat hukum adat. Penegasan kembalibahwa masyarakat hukum adat sebagai kesatuandengan tanah yang didudukinya memiliki hubungan yang sangat erat. Hubungan tersebut bersumber pada pandangan yang bersifat religius magis. Hubunganyang bersifat religus magis ini menyebabkan masyarak hukum adat memperoleh hak untuk menguasai tanah 
tersebut, memanfaatkan tanah itu, memungut hasil dari tumbuh-tumbuhan yang hidup di atas tanah itu, juga berburu terhadap binatang-binatang yang hidup disitu. Hak masyarakat hukum adat atas tanah itu disebut hak pertuanan atau hak ulayat, dan dalam literatur hakini oleh Van Vollenhoven disebut beschikking srecht(Bushar Muhammad, 1981)

\section{Peraturan Menteri (Permen) Negara Agraria/Kepala BPN tentang Pedoman Penyelesaian Masalah Hak Ulayat Masyarakat Hukum Adat}

Permen yang dijanjikan Menteri Agraria untuk mengakui keberadan tanah ulayat dalam saresehan Kongres Masyarakat Adat Nusantara ini diterbitkan tanggal 24 Juni1999, mendefinisikan Hak Ulayat dalam Pasal 1 ayat (1): Hak ulayat dan yang serupa itu dari masyarakat hukum adat, (untuk selanjutnya disebut hak ulayat), adalah kewenangan yang menurut hukum adat dipunyai oleh masyarakat hukum adat tertentu atas wilayah tertentu yangmerupakan lingkungan hidup para warganya untuk mengambil manfaat dari sumber daya alam, termasuk tanah, dalam wilayah tersebut, bagi kelangsungan hidupdan kehidupannya, yang timbul dari hubungan secara lahiriah dan batiniah turun-temurun dan tidak terputus antara masyarakat hukum adat tersebut dengan wilayah yang bersangkutan.

Perlu ditegaskan di sini bahwa UUPA berpangkal pada pendirian, bahwa untuk mencapai apa yangditentukan dalam pasal 33 ayat (3) Undang-Undang Dasar tidak perlu dan tidaklah pula pada tempatnya,bahwa bangsa Indonesia ataupun Negara bertindaksebagai pemilik tanah. Adalah lebih tepat jika Negara, sebagai organisasi kekuasaan dari seluruh rakyat (bangsa) bertindak selaku Badan Penguasa. Dari sudut inilah harus dilihat arti ketentuan dalam pasal 2 ayat(1) yang menyatakan, bahwa "Bumi, air dan ruang angkasa, termasuk kekayaan alam yang terkandung di dalamnya, pada tingkatan yang tertinggi dikuasai oleh Negara". Sesuai dengan pangkal pendirian tersebut di atas perkataan "dikuasai" dalam pasalini bukanlah berarti "dimiliki", akan tetapi adalah pengertian, yang memberi wewenang kepada Negara, sebagai organisasi kekuasaan dari Bangsa Indonesiaitu, untuk pada tingkatan yang tertinggi : a) mengatur dan menyelenggarakan peruntukan, penggunaan, persediaan dan pemeliharaannya; b) menentukan dan mengatur hak-hak yang dapat dipunyai atas (bagiandari) bumi, air dan ruang angkasa itu; c) menentukandan mengatur hubungan-hubungan hukum antara orangorang dan perbuatan-perbuatan hukum yang mengenai bumi, air dan ruang angkasa.Kekuasaan Negara atas tanah yang tidak dipunyai dengan sesuatu hak oleh seseorang atau pihak lainnya adalah lebih luas dan penuh. Dengan berpedoman pada tujuan yang disebutkan di atas Negara dapat memberikan tanah yang demikian itu kepada seseorang atau badan hukum dengan sesuatu hak menurut peruntukan dan keperluannya, misalnyahak milik, hak guna usaha, hak guna bangunan atau hak pakai atau memberikannya dalam pengelolaankepada sesuatu Badan Penguasa (Departemen, Jawatan atau Daerah Swatantra) untuk dipergunakan bagi pelaksanaan tugasnya masing-masing (pasal 2 ayat 4). Kekuasaan Negara atas tanah tanah ini pun sedikit atau banyak dibatasi pula oleh hak ulayat dari kesatuan-kesatuan masyarakat hukum adat, sepanjang menurut kenyataannya hak ulayat itu masih ada. Hak atas tanah sebagaimana telah dijelaskan dimuka, adalah merupakan wewenang yang melekatpada pemegang hak atas tanah termasuk pulah pemegang hak ulayat dengan tidak diakuinya keberadaan hak ulayat masyarakat hukum adat, maka telah terjadi pelanggaran terhadap hak-hak atas tanah masyarakat hukum adat yang harusnya diakui secara sukarelah oleh negara tanpa menetapkan standar normatif, karena wewenang tersebut sebenarnya telahada jauh sebelumnya Indonesia merdeka. Wewenangyang melekat pada pemegang hak atas tanah secara normatif telah dilindungi oleh undang-undang. Selanjutnya dalam UUPA telah menegaskan bahwa hierarkhi hak-hak atas tanah di Indonesia menempatkan posisi hak ulayat masyarakat hukum adat merupakan salah satu rangkaian hak-hak penguasaan atas tanah (Urip Santoso, 
2017). Oleh karenanya menurut Boedi Harsono tidak ada alasan untuk meragukan bahwa yang dimaksudkan UUPA dengan hukum adat itu adalah hukum asli golongan rakyat pribumi, yang merupakan hukum yang hidup dalam bentuk tidak tertulis dan mengandung unsur-unsur nasional yang asli, yaitu sifat kemasyarakatan dan kekeluargaan yang berasaskan keseimbangan serta diliputi suasana kegaamaan (Boedi Harsono, 2008).

\section{KESIMPULAN}

Sesuai dengan uraian hasil pembahasan yang telah disajikan suda tentu kita dapat menarik kesimpulan yang akan kita ambil dimana pada konflik antara warga Masyarakat dengan TNI-AU disebabkan klaim tana yang dimiliki masing-masing dari pihak AURI berdasarkan pada regulasi hak tanah pemerinta sementara masyarakat mengakui tanahnya karna sejak turuntemurun masyarakat berkebun dengan

\section{DAFTAR PUSTAKA}

Boedi Harsono (2008). Hukum Agraria IndonesiaSejarah Pembentukan Undang-Undang Pokok Agraria, Isi dan Pelaksanaannya, PTDjamabata, Jakarta.

Husen Alting.2013.Konflik Penguasaan Tanah di Maluku Utara Rakyat Versus Penguasa dan Pengusaha. Jurnal dinamika hukum. Vol 13.No 2

Hendro puspito.1992.Politikologi. Erlangga

Mawuntu, J Ronald. "Konsep Penguasaan Negara Berdasarkan Pasal 33 UUD NRI Tahun 1945 dan Putusan Mahkamah Konstitusi". Jurnal Konstitusi. Vol. XX. No. 3. April-Juni 2012. Menado: PKK FH Unsrat; dibuktikah hasil tani hultikultura seperti pohon kelapa dan mangga yang suda berumur sekitar ratusan tahun lamanya. Adanya upaya memfasilitasi dari pihakpihak pemerintah untuk mencari win-win solution dengan mempertemukan kedua belah pihak tetapi belum mendapatkan keputusan yang adil diantara kedua pihak saling mempertahankan pendapat mereka masing-masing dari pihak AURI berpendapat bahwa wilayah yang dipatok adalah wilayah landasan pacu bandara sedangkan masyarakat merasa tanah yang selama ini digarap dari hasil pertanian merupakan hak tanah mereka. Berbagai upaya pemerintah daerah untuk meyelesaikan permasalah sengketa tanah ini ketika timbul konflik seperti pencabutan patok AURI yang dilakukan masyarakat, pembongkaran fondasi rumah oleh AURI yang dibangun masyarakat yang sudah masuk pada wilayah bandara pitu yang termasuk kawasan patok AURI.

Urip Santoso (2017). Hak Atas Tanah, Hak Pengelolaan, Dan Hak Milik Atas Satuan Rumah Susun, Pt Kencana, Cimanggis.

Peraturan Menteri Negara Agraria/Kepala BPN tentang Pedoman Penyelesaian Masalah Hak Ulayat Masyarakat Hukum Adat

Undang-Undang Dasar Negara Republik IndonesiaTahun 1945

Undang-Undang Nomor 5 Tahun 1960 Tentang Peraturan Dasar PokokPokok Agraria.

Undang-Undang Nomor 41 Tahun 1999 Tentang Kehutanan

Undang-Undang Nomor 32 Tahun 2009 Tentang Perlindungan dan Pengelolaan LingkunganHidup

Undang-Undang Nomor 6 Tahun 2014 TentangDes 